\title{
Another Recession, But Different
}

\author{
DENIS S. KARNOSKY
}

T

HE QUESTION of whether or not the economy entered into a period of recession in 1974 has been a popular topic of discussion. To date the National Bureau of Economic Research, unofficially charged with making the distinction, sees the controversy as too close to call. But, the issue of tagging 1974 with the label of "recession" is, by itself, of little significance. What is important is the common interpretation of what a period of recession means in terms of economic activity and the monetary and fiscal policies that are appropriate to deal with the situation. growth of total employment through most of the year and the sharp acceleration in the rate of price increase. The table below reports the rates of change of prices, production, and employment in each of the five official recessions since 1947 and the immediately prior years. The experiences of 1973 and 1974 are shown for contrast. Employment typically declined in the post-war recessions and, while the average level of prices did not generally fall during these prior periods, the rate of increase has tended to decrease substantially or at least to cease accelerating. ${ }^{1}$

Economic stabilization policy has come to be concerned primarily with influencing the growth of aggregate demand as a means of achieving employment and price goals. While not universal, the belief is widely held that judicious actions can keep demand growing in line with productive capacity and thereby minimize fuctuations in unemployment and maintain price stability. As a result, economic recessions and the associated increases in the rate of unemployment have been attacked through programs designed to stimulate growth of demand. The relevant question currently is what could have been done, in terms of influencing the growth of aggregate demand, to forestall the developments of 1974 and what programs are now appropriate.

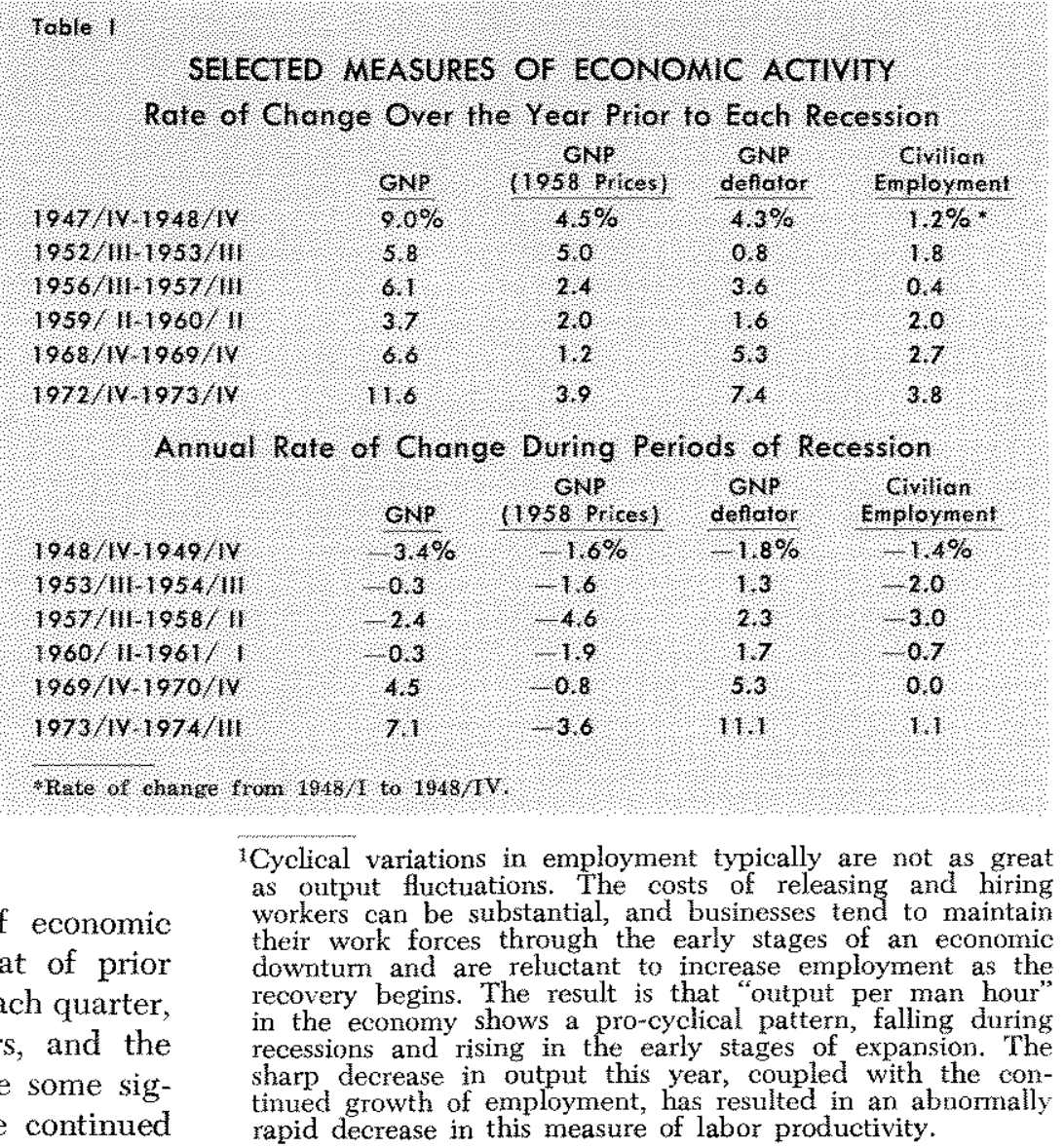

Annual Rate of Change During Periods of Recession

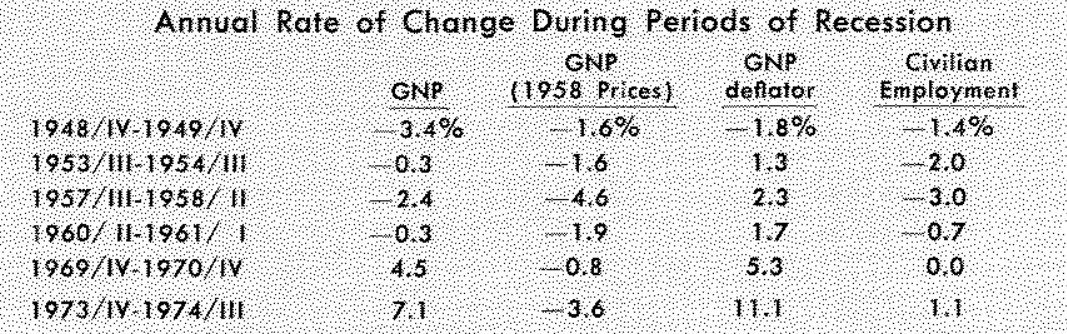

trate of ohange fron $1048 / 1$ to $1048 \mathrm{HV}$

TCyclical variations in employment typically are not as great as output fluctuations. The costs of releasing and hiring workers can be substantial, and businesses tend to maintatin their work forces throngh the early stages of an economic downtum and are reluctant to increase employment as the recovery begins. The restlt is that "oulput per man hour" in the economy shows a pro-cyclical pattern, falling during recessions and rising in the early stages of expansion. The sharp decrease in output this year, coupled with the contmued growth of employment, has resulted in an aboomally rapid decrease in this measure of labor productivity.

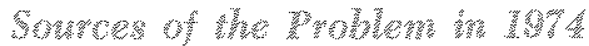

In many obvious ways the pattern of economic activity in 1974 has been much like that of prior recessions. Total production has fallen in each quarter, demand has weakened in several sectors, and the rate of unemployment is rising. There are some significant differences, however, such as the continued 
These differences are related to the major element which distinguishes the experience of 1974 from the five recessions of the post-war period. Each of the five recessions between 1947 and 1971 resulted exclusively from a restriction of the growth of aggregate demand. Compared to these periods, however, growth of aggregate demand slowed only moderately in 1974, with total spending growth falling to an annual rate of 7.1 percent for the first three quarters of the year from an 11.6 percent increase over the prior year. Interpreting the growth of total spending as indicative of the rate of expansion of aggregate demand, a reduction of this magnitude is not sufficient to explain the decrease in the rate of production experienced so far this year.

Over the period from 1953 to 1971 a historical relationship between monetary and fiscal policy actions on the one hand and the growth of total real output in the economy on the other would imply an output growth at about a 2.5 percent annual rate over the first three quarters of $1974 .^{2}$ While this empirical relationship does not provide a basis for predicting all of the quarterly variation in output over a period, the differences between the reported rate of growth of output in 1974 and the change in output that is implied by past relationships is sufficiently large to warrant a look towards "special factors" that may have played a part in this abnormal development.

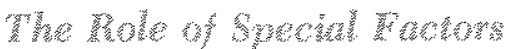

As far as the production of goods and services goes, the events of the past few years seem to confirm the validity of Murphy's Law, which essentially predicts that in a given situation anything that can go wrong will. The economy has been buffeted by an unprecedented assortment of so-called outside influences. Many of the events would not pose serious problems if they occurred separately; but occurring almost simultaneously, the effect has been substantial

\footnotetext{
-There are many empirical models which attempt to capture the relationship between monetary and fiscal actions and measures of economic activity. The results reported here are from only one such model and others might give different results. A crude indication of the predictions of these other models can be obtained by averaging the forecasted rates of output change from several models for the first three quarters of 1974. In December 1973 , a representative sample of these models predicted, on average, that the rate of increase of real product would be at a 1.2 percent annual rate. See The Conference Baard Statistical Bulletin (December 1973) p. 5. For a presentation of the model used here see Leonal C. Andersen and Denis S. Karnosky, "The Appropriate Time Frame for Controlling Monetary Aggregates: The St. Louis Evidence," Controlling Monetary Aggregates 11 : The Implementation, Conference Series No. 9, Federal Reserve Bank of Boston, 1972, pp. 147-177.
}

indeed. The problems have been made even more severe by current and past price controls and government allocation programs.

The weather both here and abroad resulted in widespread crop losses and intense pressure in our agricultural markets. This was worsened by the mysterious disappearance of anchovies (a prime source of protein) from the Peruvian coast. The dollar has depreciated by a weighted average of 15 percent against the ten major world currencies. New environmental laws were implemented in order to reduce air, water, and noise pollution. Occupational and product safety laws were pressed. Major oil-exporting countries colluded first to impose a partial embargo on exports of petroleum to the United States and then to increase sharply prices for crude and refined oil products. Each of these events represents a substantial and unforeseen shock to the economy. Whatever the long-term benefits of any of these actions, all have led to substantial increases in the cost of producing some goods and services, at least in the short-run. This increase in cost is responsible for much of the decline in production experienced in 1974.

There have been instances in the past, such as in the case of major labor strikes, when the output of the economy has been cut sharply, but the effect has tended to be very short-lived and quickly reversed. During the period of a major strike, machinery and workers, both capable of producing goods and services, are voluntarily idle. The willingness of the concerned businesses and workers to produce is decreased. When the strike is settled, employment of machinery and workers is resumed and production begins anew. The situation in 1974 is similar, except the problem is not one of labor-business intransigence, and the consequences are much more pervasive. The rate of output in the economy has been decreased markedly and prices are sharply higher as a result.

The effects of some of these special factors are short-lived, while others threaten to last for some time. Many of the factors which have tended in some way to depress ontput and increase domestic prices are international in nature, related to the interdependence of world economies. Domestic developments have also contributed to the problem, either as sources of additional stress or as agents which magnify the effects of foreign influences. The effect of these factors in the last three years has been to intensify the internal stress in an economy already taut under the pressure of persistent excessive aggregate demand. 


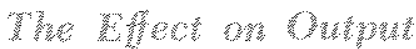

In a market system resources flow back and forth in pursuit of the highest expected rewards. In an ideal setting there is a general wealth of information about production opportunities and there are no impediments to movements of capital, labor, and technology between markets. In fact, however, the structure of the economy is very rigid in many respects and resource movements often are impeded in the short run. Actions once taken are costly to reverse. Because of these costs, shifts in demand in the economy can result in temporary, but often long-lasting, distortions in economic activity, with increased unemployment in some industries and excess demand for labor in others. Machinery designed to produce one commodity is not easily converted to the production of another. Workers cannot be re-employed quickly in different professions or in other parts of the country. The economy is continuously subjected to such structural problems, but for the most part the system has been able, at least until the past few years, to handle the normal, frequent shifts of resources without exceptionally large economic distortions.

Costs of adjusting to shifts in demand have a bearing on the productive capacity of the economy, at least in the short-run. For example, with a given growth rate of aggregate demand, a shift in the public's preference from defense to nondefense goods, say from military aireraft to cosmetics, does not affect the ability of the existing machinery and labor to produce aircraft. There will be less aircraft produced, however, as the incentive of the aircraft manufacturers to produce is cut. There is less demand for their product at current prices. Unless there is idle capacity in the cosmetic industry, the increase in output of cosmetics would not be as great as the increase in demand, as resources are not attracted immediately into the industry. For some period of time, the economy suffers a decrease in total production, manifested in the aircraft industry, but not fully offset by increased production of cosmetics. In an engineering sense the productive capacity of the economy is unaffected. Technically, the economy would still be abte to produce as many aircraft as before. Economic capacity is reduced, however, because the incentive to produce airplanes has fallen. Fewer aircraft could then be produced at a price which covers costs. In an economic sense, a portion of the productive facilities of the aircraft industry become obsolete.

It is clear that the sharp restriction on oil importation last winter accounted for much of the economic problems early in the year. The reduction in the sup- ply of petroleum products caused many forms of economic activity to be curtailed and the total output of the United States decreased sharply. The embargo ended in March, but, while the How of oil into the country resumed, the depressive effect on economic activity continued. The consumption of oil is now growing at a slower rate than prior to the embargo, due to the formation of a cartel among oil exporting countries and markedly higher price. It is the increase in the price of oil which now contributes to our problems.

Machinery which required petroleum products in the production process and which could be run efficiently at a crude oil price of $\$ 2.50$ a barrel can become less efficient, or even obsolete, when the price of oil goes up to $\$ 10$ a barrel. Alternatively, the most efficient uses of oil change when the price rises, and substitutes for oll, which were more expensive to use when oil was available at the old price, become more efficient in use. The adjustment to this change in relative prices cannot be accomplished quickly, however, and in the interim the productive capacity of the system is decreased.

Petroleum products are now more expensive in terms of other goods and services. On the one hand the United States must now give up more commodities to purchase oil from the cartel - if not now, then at some time in the future. Domestically, it is no longer efficient to use oil in the same ways as in the past. Internal adjustments are required. Just as the old patterns of activity must be altered because they are inconsistent with public demand for cleaner air and water, a safer working environment, and increased product reliability and safety, the way in which we have done many things has been made obsolete by the actions and threats of the cartel of oil-exporting countries. At the new, higher oil prices many of the ways that petroleum products had been used prior to the embargo have become wasteful.

This effect is most apparent in the automotive industry, where sales are down sharply. The industry typically suffers a sales slump when growth of aggregate demand slows, but the current problems can be traced in large part to structural difficulties. Late in 1973 and early this year the oil embargo, rising gasoline prices, and government fuel allocation programs increased the attractiveness of small cars relative to large automobiles. Total auto production decreased, however, because of the costs and time necessary for producers to alter their operations to meet this shift in consumer preference. In addition, the demand for cars in general has been decreased by the increase in 
the cost of operation, not just from higher fuel and oil prices but also by the additional costs of safety and environmental devices. The problem in the automotive industry is not one of inadequate aggregate demand, but instead reflects the effects of shifts in demand within the economy.

The impact of the changed oil situation and the environmental and other laws has been intensified in the economy by other restrictions which inhibit the movement of resources. Information about production opportunities are transmitted via relative price changes. Price increases in an industry serve as a signal that there might exist an opportunity for gainful employment in that industry. The normal adjustment mechanism was short-circuited in 1971, however, by the implementation of price controls, on both goods and labor services. The sudden and widespread reports of "shortages" of many items are ample evidence of the distortions created by the controls.

The effects on total production of sudden shifts in demand will tend to be temporary and, without further attempts to control prices or allocate resources, the adjustment will proceed until total production is restored. In addition to the temporary effects on current production of adjustment to $\mathrm{ex}$ traneous shocks, the economy's ability to produce has been reduced permanently, to some extent. Some environmental controls have rendered existing productive processes and equipment obsolete. The external quadrupling of oil prices, combined with the price controls and mandatory allocation programs applied to domestic oil, ultimately reduced the amount of oil available for domestic production. The depreciation of the dollar in international markets from artificially high rates has decreased the amount of productive resources that have been previously acquired through imports. Thus we had not only a temporary decrease in the wealth of the country, but also a permanent one.

\section{Summarat}

Given such increases in the prices at which productive resources are available, it is not surprising that it sharp decline in ontput and an acceleration in the increase of the price level resulted. This, of course, explains neither the rate of inflation that existed prior to 1973 nor a decline of output growth that would have resulted from the effects of price and wage controls. But a large part of the sharp changes that occurred in 1974 can be attributed to exogenously induced resource losses.

This being the case, traditional stabilization policies designed to stimulate aggregate demand are likely to produce even further accelerating inflation without stimulating output growth. It seems reasonable that the adjustments to internal stresses and to the decrease in available resources are coming to an end and that even without any new and different stabilization policies, inflation will return to the path dictated by the growth in output and money stock; output growth, in turn, will return to the path produced by the growth of resources and technology. One thing that no aggregate demand policy will be able to wipe out is the fact that these exogenous shocks have made us poorer: the output level will remain below, and the price level will remain above what it would have been in the absence of these resource losses.

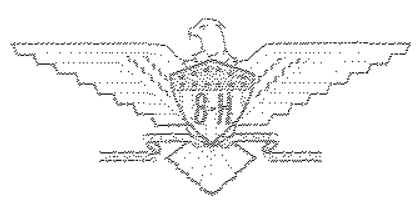

